\title{
Regional hydrogeology of the Tokaj Mountains world heritage site, North-East Hungary
}

\author{
Zoltán FEJES ${ }^{1}$, Péter SZÜCS ${ }^{2 *}$, Endre TURAI ${ }^{3}$, Balázs ZÁKÁNYI ${ }^{4}$ and Norbert Péter \\ SZABÓ
}

\author{
Authors' affiliations and addresses: \\ ${ }^{1}$ Institute of Environmental Management, \\ University of Miskolc, 3515 Miskolc, \\ Egyetemváros, Hungary, \\ e-mail: zoltan.fejes87@gmail.com \\ ${ }^{2}$ Institute of Environmental Management, \\ MTA-ME Geoengineering Research Group. \\ University of Miskolc, 3515 Miskolc, \\ Egyetemváros, Hungary, \\ e-mail: hgszucs@uni-miskolc.hu \\ ${ }^{3}$ Institute of Geophysics and Geoinformatics, \\ University of Miskolc, 3515 Miskolc, \\ Egyetemváros, Hungary, \\ e-mail: gfturai@uni-miskolc.hu \\ ${ }^{4}$ Institute of Environmental Management, \\ University of Miskolc, 3515 Miskolc, \\ Egyetemváros, Hungary, \\ e-mail:hgzb@uni-miskolc.hu \\ ${ }^{5}$ Institute of Geophysics and Geoinformatics, \\ MTA-ME Geoengineering Research Group. \\ University of Miskolc, 3515 Miskolc, \\ Egyetemváros, Hungary, \\ e-mail: gfnmail@uni-miskolc.hu
}

\section{*Correspondence:}

Péter Szücs, Institute of Environmental Management, MTA-ME Geoengineering Research Group. University of Miskolc, 3515

Miskolc, Egyetemváros, Hungary,

e-mail: hgszucs@uni-miskolc.hu

\section{Acknowledgement:}

The research was carried out within the GINOP-2.3.2-15-2016-00031 "Innovative solutions for sustainable groundwater management" project of the Faculty of Earth Science and Engineering of the University of Miskolc in the framework of the Széchenyi 2020 Plan, founded by the European Union, cofinanced by the European Structural and Investment Funds.

How to cite this article:

Fejes, Z., Szücs, P., Turai, E, Zákányi, B. and Szabó, N. P. (2021). Regional hydrogeology of the Tokaj Mountains world heritage site, NorthEast Hungary. Acta Montanistica Slovaca, Volume 26 (1), 18-34

DOI:

https://doi.org/10.46544/AMS.v26i1.02

\begin{abstract}
Tokaj Mountains, as a large Miocene volcanic region in North-East Hungary, is the homeland of the famous Tokaj wine. The Tokaj wine region can be found on the world heritage list of UNESCO. Although there were several mineral prospecting activities at the Tokaj Mountains in the 1960s and 1970s, the groundwater resources on a regional scale have not been revealed yet. The regional water budget and the groundwater flow systems were not known before the complex hydrogeological investigations recently carried out by the University of Miskolc. Although shallow groundwater is being produced at some small-scale waterworks to cover local drinking water demands, it has believed that there is no chance to find thermal water and to extract underground heat in this volcanic area because of the average hydraulic conductivity of the subsurface formations is very low. It is encouraging that intensive tectonic lines were determined by geophysical methods during the recent field campaigns. The presence of valuable thermal water resources was discovered along these tectonic lines opening new perspectives in geothermal exploration in this region. After the extensive field measurements, a regional scale groundwater-flow model was constructed to characterize the subsurface flow systems and the available shallow and deep groundwater resources of the Tokaj Mountains. A special prospecting methodology involving geological, hydrogeological and surface geophysical methods was elaborated to find thermal water resources in this complex geological/ecological environment.
\end{abstract}

\section{Keywords}

Tokaj Mountains, hydrogeophysical, hydrogeological modelling 


\section{Introduction}

The volcanic Tokaj Mountains are located in North Hungary and divided by the Hungarian and Slovakian border. This UNESCO world heritage region is famous for the well-known Tokaj wine. The total length of the Tokaj Mountains is about 100 - $120 \mathrm{~km}$ Tokaj and Eperjes (Slovakia) (Kiss, 2007). The thermal water and geothermal energy prospecting purposes in the Tokaj Mountains always have secondary importance from the point of view of hydrogeologists due to its complex geological structure and the insufficient number of exploration deep wells. The University of Miskolc initiated a large scale research program in 2012 in order to discover and map the available groundwater resources of the Tokaj Mountains. During this intense research program, it was realized that despite the complex geological structure, many potential thermal aquifers can be found in the investigated area. One of the aims of this research program was to determine the hydrological parameters of the thermal aquifers and geothermal gradient of the area using geophysical and numerical methods (Szücs et al., 2014).

Mainly raw material research programs had been conducted earlier in the Tokaj Mountains. This is the reason why only limited information about groundwater resources and geothermal conditions was available in this region at the beginning of the above-mentioned research program. As a result, it was concluded that there is no chance to find thermal water in this region. Cold water springs and wells are dominant in the higher areas of the Tokaj Mountains, but some thermal and lukewarm springs and wells at the edge zones are good indications of the geothermal potential (Madarász, 2015). All available lukewarm springs and wells found mainly in the west part of the Tokaj Mountains were involved in the complex hydrogeological investigation and interpretation. The thermal indications on the west side coincide with the positions of the main tectonic lines, which are closely North-South directions and parallel with the Hernád valley. These thermal indications represented by settlements are the following from the North to South: Kéked, Gönc, Korlát, Vizsoly, Boldogkőváralja, Bekecs and Szerencs (Fig. 1).

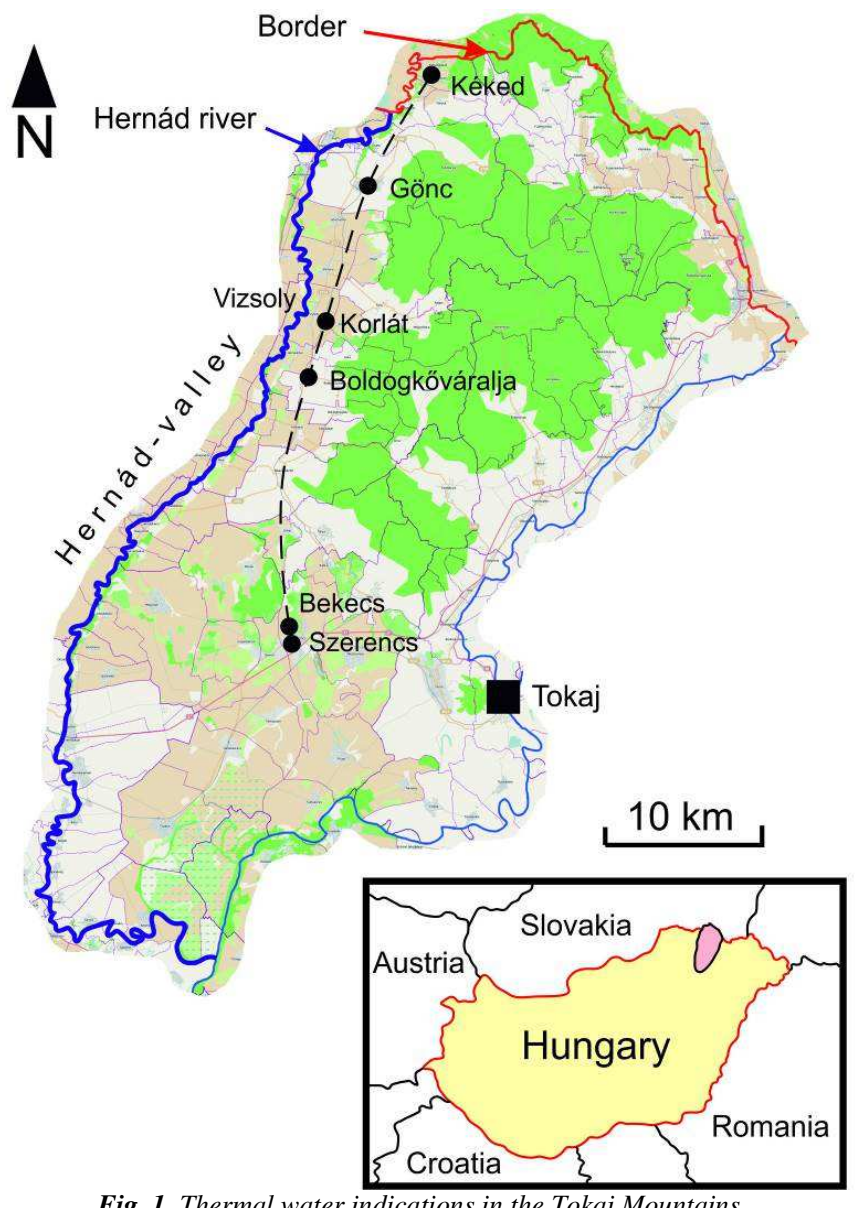

Fig. 1. Thermal water indications in the Tokaj Mountains.

\section{Geological settings}

The investigated area has mainly impounded by natural boundaries. The boundary at North is the HungarianSlovak border, which has the highest topographical elevation in the area. The West boundary is located along the Hernád-valley. Actually, this is a structural line, described as the ALCAPA-Tisza tectonic zone, a part of the Central-Hungarian lineament. The Tisza and Sajó Rivers form natural boundaries at the South side of the area. In 
a smilar way, the East border lines are the Tisza and the Bodrog rivers. The geological structure of the Tokaj Mountains is very complicated. The real depth and the rock material of the basement are not known. It is only a rough estimation that the depth of the basement is around 1500-2000 $\mathrm{m}$ under the surface. The basement material is probably metamorphic mica. Concerning the complex geological structure of the investigated area, it was proved by some wells that the Triassic thermal karst at Sárospatak is also present. This means that the Neogene vulcanite formations are rather deep. The volcanism started in the Miocene and ended in the Lower-Pannonian in this region. The Upper Pannonian clastic sediments pinched-out at the South area, but toward the Great Hungarian Plain the thickness of the sediments is continuosly increasing. In many palces, Pleistocene fluvial sediments have been formed in large thickness above the Pannonian formations. Genereally, the Holocene formations are negligible in the Tokaj Mountains. Figure 2 shows the simplified geological model of the Tokaj Mountains.

All manuscripts must be prepared in English (either British or American English can be used, but be consistent within the manuscript), together with tables and figures inserted into the text, otherwise we cannot publish your paper.

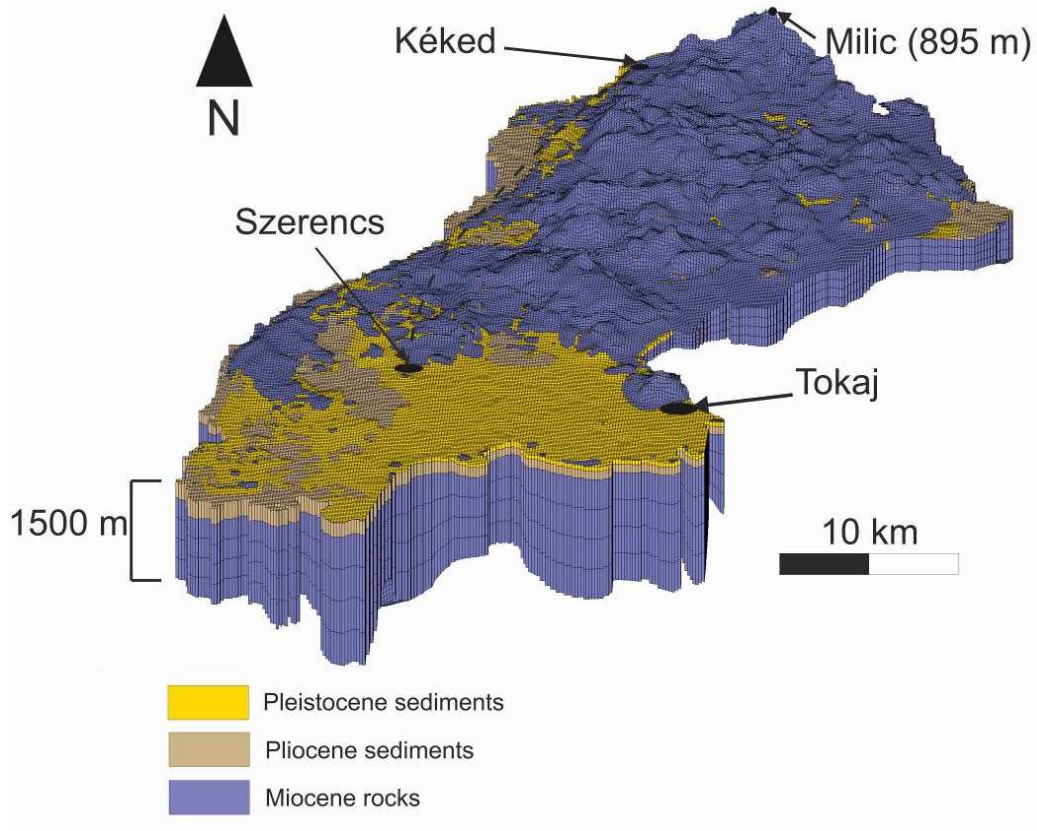

Fig. 2. The simplified geological model of the Tokaj Mountains.

\section{Hydrogeological settings and conceptual model}

The described layers of the Tokaj Mountains have different hydrogeological properties. The Pleistocene and Pliocene sediments generally have good hydraulic conductivity and porosity, but these layers are located in a shallow position. The Miocene rock formations are nearly impermeable. This means that groundwater can flow only through the fractures and the conductive faults. The inner highland part of the mountains is the infiltration or the recharge area. Due to the gravity, some part of the precipitation infiltrates and flows down through fractures to the edges of the mountains. At the edge of the mountains, there are two structural lines (Hernád and Bodrog lines), through which the water rises rapidly close to the surface (Fig. 3) (Molnár, 2010). Figure 4 shows the newly created conceptual flow model of the Tokaj mountains. This new conceptual flow model is based on the available hydrogeological data as well as on the realized field measurements and the observations. The edges of the mountains have got a lot of thermal and tepid water anomalies, which can be detected easily in the wells and springs. The outflow groundwater temperatures of the investigated wells and springs are around $18-31{ }^{\circ} \mathrm{C}$. These are well-known facts that the average geothermal gradient is about $5^{\circ} \mathrm{C} / 100 \mathrm{~m}$, and the mean annual air temperature in Hungary is about $9-11^{\circ} \mathrm{C}$ (Bobok et al., 2014). Thus, the depth of these flow paths is approx. 200$400 \mathrm{~m}$ deep. This calculated depth is the actual depth of the youngest lava rock formations. The tepid and thermal water anomalies designate a long fracture in the north and south direction. The northernmost anomaly is located in Kéked, then the next ones from North to South: Pányok, Gönc, Korlát, Hernádcéce, Abaújszántó, Boldogkőváralja, Bekecs, and then Szerencs (Fig. 3). Table 1 summarises the screening depth and the outflow water temperature data of the observed lukewarm water anomalies. 


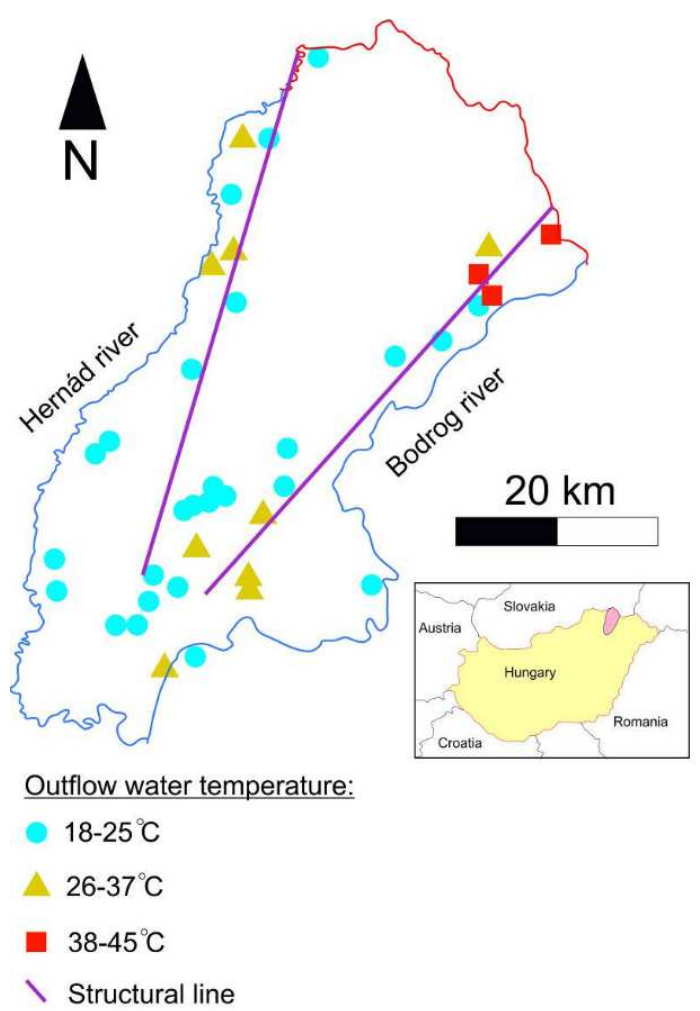

Fig. 3. Structural lines on the west and east edges of the Tokaj Mountains.

Table 1. Outflow water temperature anomalies of the Tokaj Mountains.

\begin{tabular}{|c|c|c|}
\hline Settlement & Screening depth $[\mathbf{m}]$ & Outflow water temperature [ $\left.^{\circ} \boldsymbol{C}\right]$ \\
\hline Kéked & spring & 20 \\
\hline Pányok & 28 & 31 \\
\hline Gönc & spring & 20 \\
\hline Korlát & 31 & 26 \\
\hline Hernádcéce & 302,5 & 24 \\
\hline Abaújszántó & 39 & 22 \\
\hline Boldogköváralja & 178 & 24 \\
\hline Bekecs & 60 & 21 \\
\hline Szerencs & 202 & 26 \\
\hline
\end{tabular}

Based on the available temperature information, a special groundwater flow system can be recognized in the Tokaj Mountains. The flow paths are connected to the fracture lines of the volcanic formations. The main recharge area can be found on the highest topographic area of the mountains. The discharge areas can be found at the edges of the Tokaj Mountains. The length of the flow paths can be very different. The travel time of the water particles along the shortest flow paths on the top of the mountains can be only some days. On the other hand, the travel time can be several thousand years along the longest and deepest regional flow paths. Based on the field investigations, the conceptual groundwater flow model of the investigated area can be seen in Fig. 4 (Fejes et al., 2013).

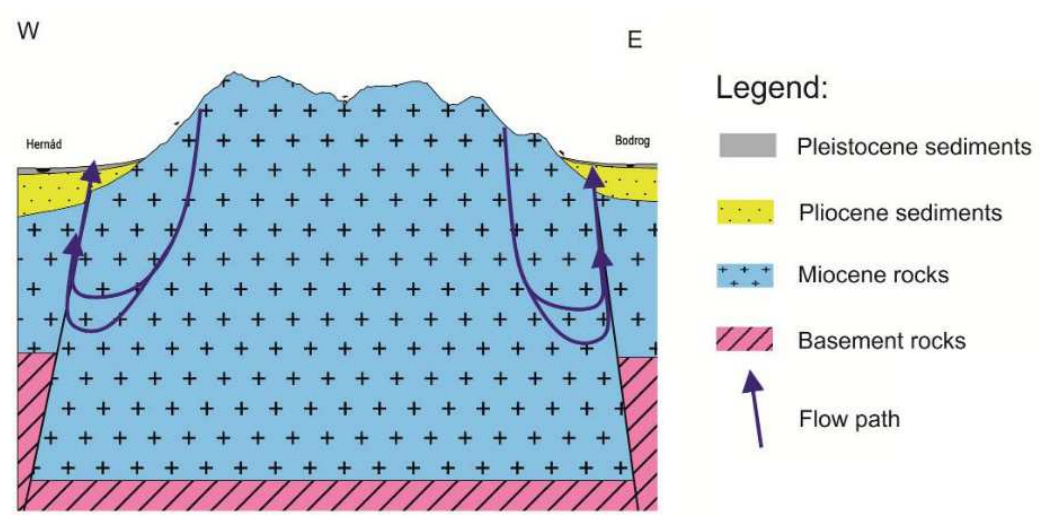

Fig. 4. The conceptual groundwater flow model of the Tokaj Mountains. 
It can be seen that the discharge zones are located on the left and right sides along the fracture lines. The recharge area is in a central position where the topography is high. This derived conceptual model is inevitable for three-dimensional flow modelling. There are three different data sources to delineate the flow lines even more preciously:

1. Using the temperature data of the wells and springs,

2. Using the water chemistry information of the wells and springs,

3. Using the environmental isotope age estimation information of the wells and springs.

\section{Description of flow paths based on geothermal data}

Some basic information about several hundred wells is available for the whole area of the Tokaj Mountains. The hydrogeological description can be carried out based on the datasets measured from these wells. It is important to underline that such a detailed regional hydrogeological description for the Tokaj Mountains has not been given before this study. The earlier different hydrogeological investigations were restricted to only small-scale local areas. The first regional-scale database was built during the current research work involving all available well and natural spring data. The newly measured data were also included in the database, which already consists of several hundreds of data samples. It can be concluded that local cold water flow systems are quite common at the high elevation recharge areas in the middle part of the mountains. On the other hand, lukewarm anomalies connected to the regional flow systems in the discharge areas are quite common at the margins of the Tokaj Mountains. The areal distribution of the apparent geothermal gradients is illustrated on the structural geology map of the Tokaj Mountains (Fig. 5). The knowledge of the fracture lines in a volcanic area is inevitable for the description of the groundwater flow. The geothermal gradients derived from the lukewarm water wells are apparent because those wells can catch upcoming water along the fracture lines in the discharge zones. The apparent geothermal gradient can be used to outline the wells screened for upcoming groundwater flow systems (Székely et al., 2015). Red circles indicate the apparent geothermal gradients larger than $10^{\circ} \mathrm{C} / 100 \mathrm{~m}$.

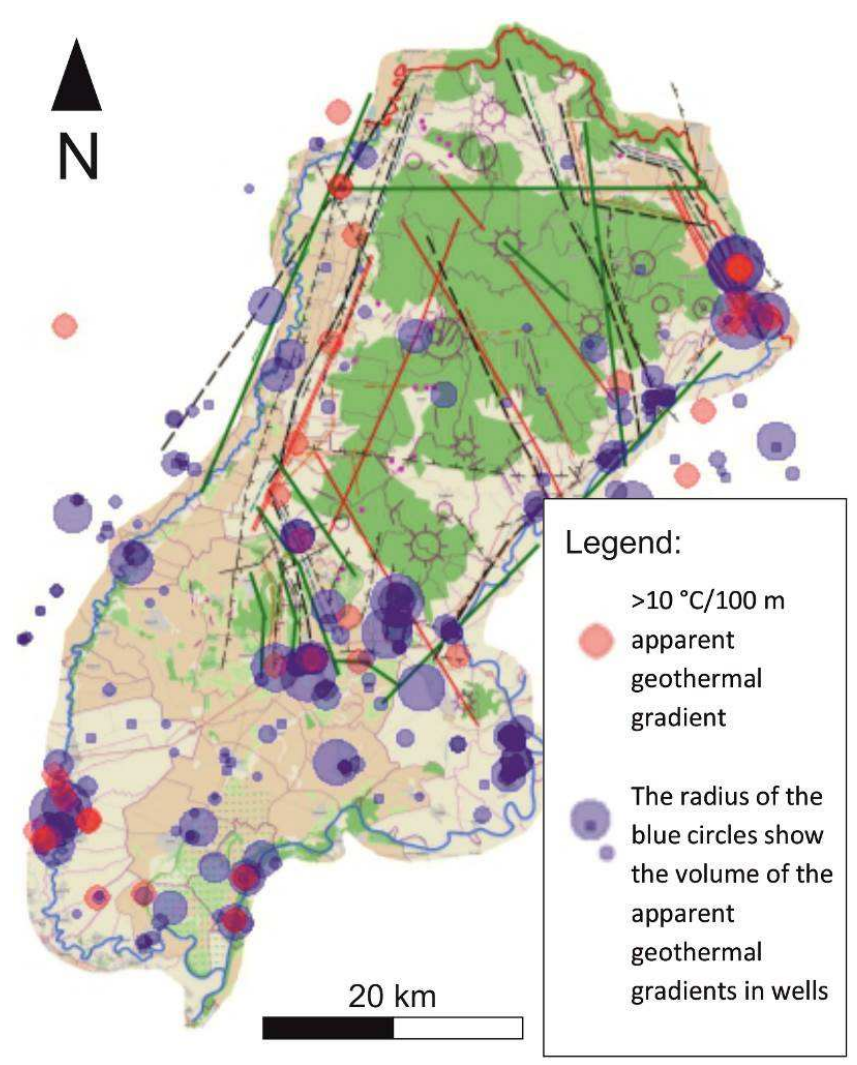

Fig. 5. Apparent geothermal gradients in the Tokaj mountains.

It can be seen in Fig. 5 that all the wells with large apparent geothermal gradients are located along the wellknown tectonic lines. The groundwater flow lines of these wells are not known. The earlier seismic depth sections and the temperature data of the investigated wells can be used to derive some relations connected to the groundwater flow systems. 


\section{Description of groundwater flow lines based on water chemistry information}

All the earlier collected water chemistry data were also inserted into the extended database. Some new measurements were also carried out to increase the available data number. Broadly speaking, low TDS values are the most common in the Tokaj Mountains. Mainly calcium-sulfate-bicarbonate water is the most typical one. The magnesium and chloride content is normally low. The length and the depth of the flow paths can influence the mineral content of the groundwater. The groundwater chemistry data of the investigated wells and springs were described in Piper diagrams, where the cation and anion compositions are drawn in a rhombus diagram. In order to increase the efficiency of the interpretation, the Piper diagram was supplemented with an HSV colour system applying unique colour codes. In the HSV colour system, the measured data were identified based on colour shade (H - Hue), saturation (S - Saturation) and lucidity (V - Value) (Luk, 2013). The water chemistry data of the Tokaj Mountains are plotted in the Piper-diagram (Figs. 6-7). In these figures, the points of springs and wells were plotted separately. Then, the data with this colour scale were plotted on the geological map (Gyalog, 2015) (Figs. 8-9). It can be seen that calcium carbonate water is typical in rhyolite regions, and sulfate-carbonate water is dominant in andesite regions.

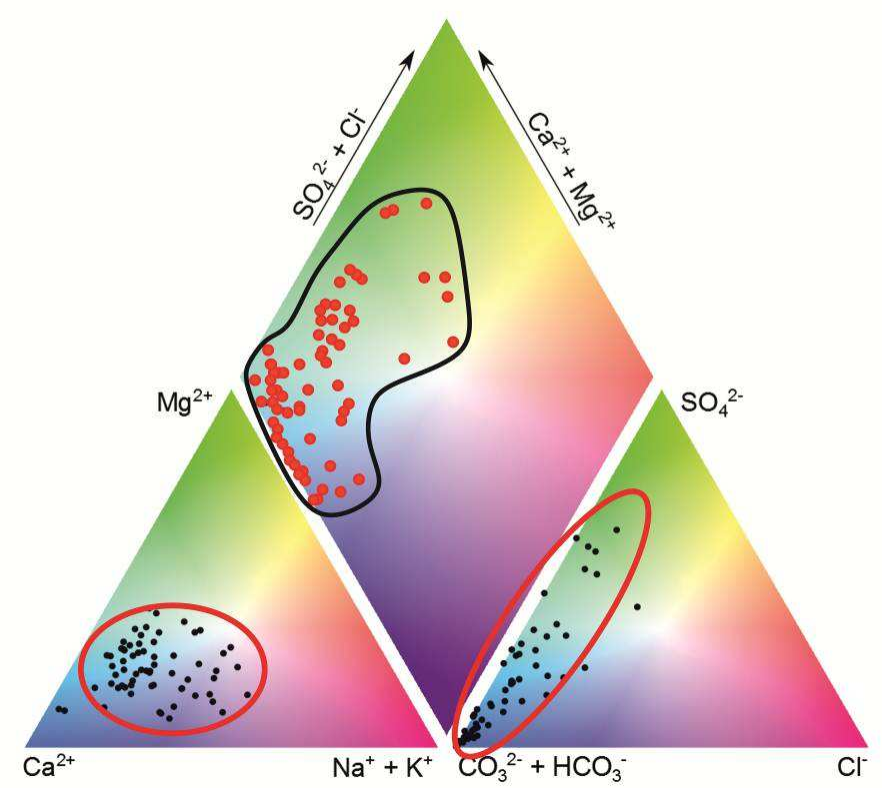

Fig. 6. Chemistry of the water samples from the springs in the Tokaj Mountains.

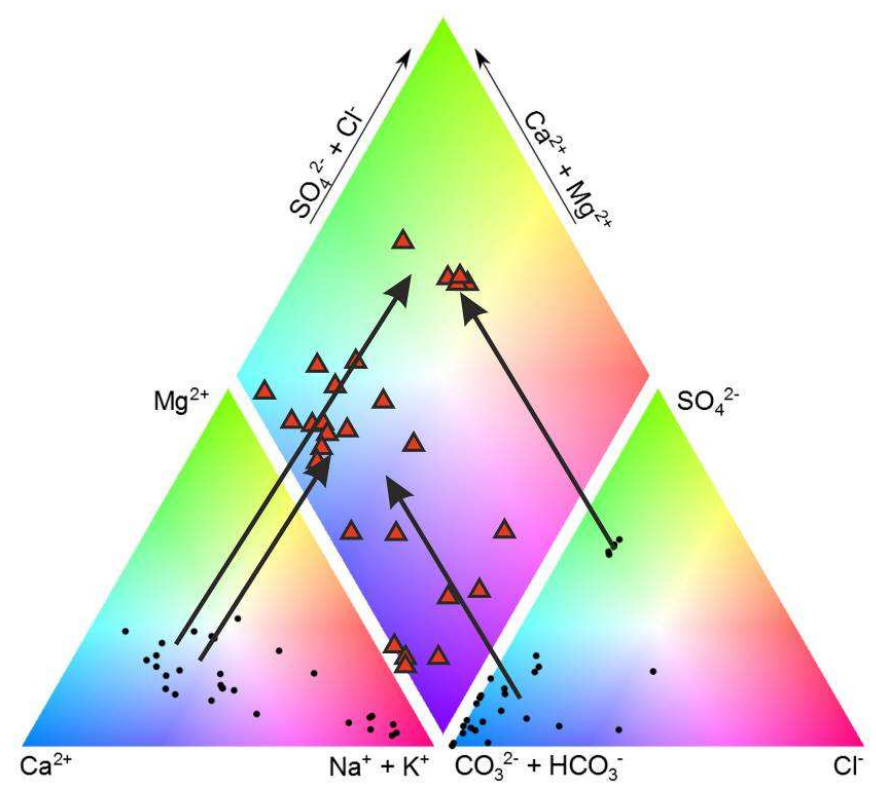

Fig. 7. Chemistry of the water samples from the wells in the Tokaj Mountains. 


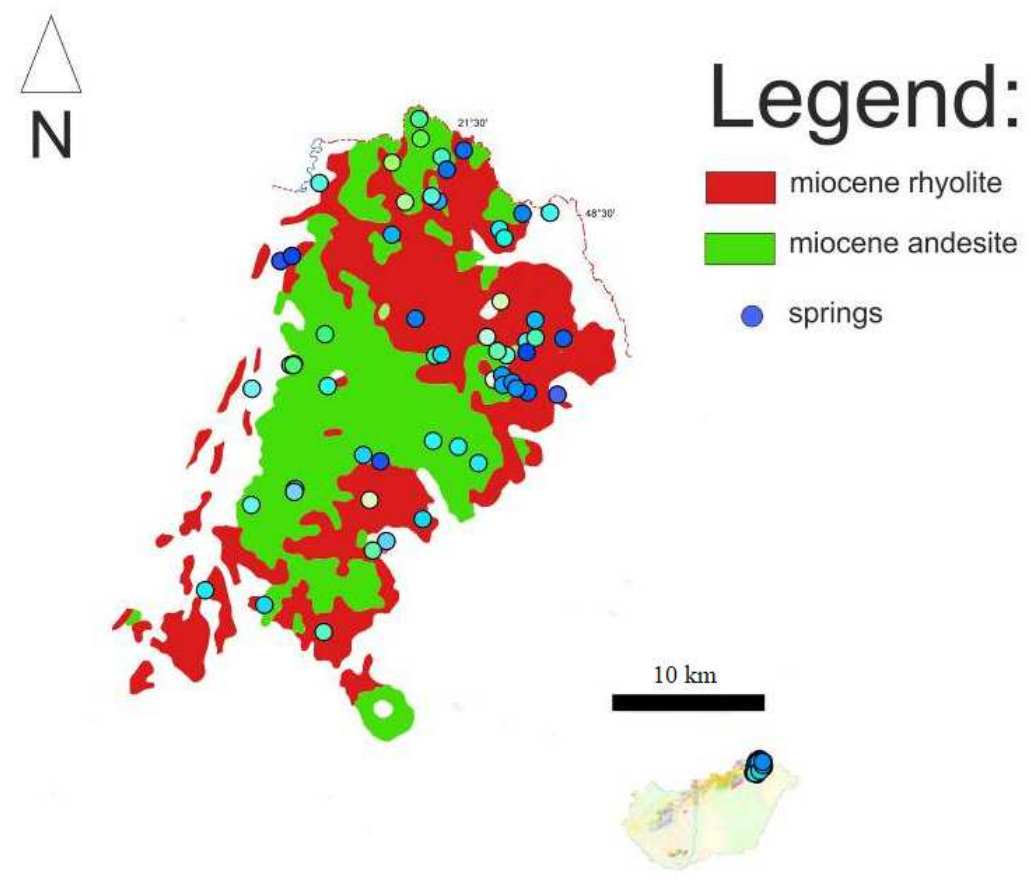

Fig. 8. Springs in the Tokaj Mountains presented on a geological map.

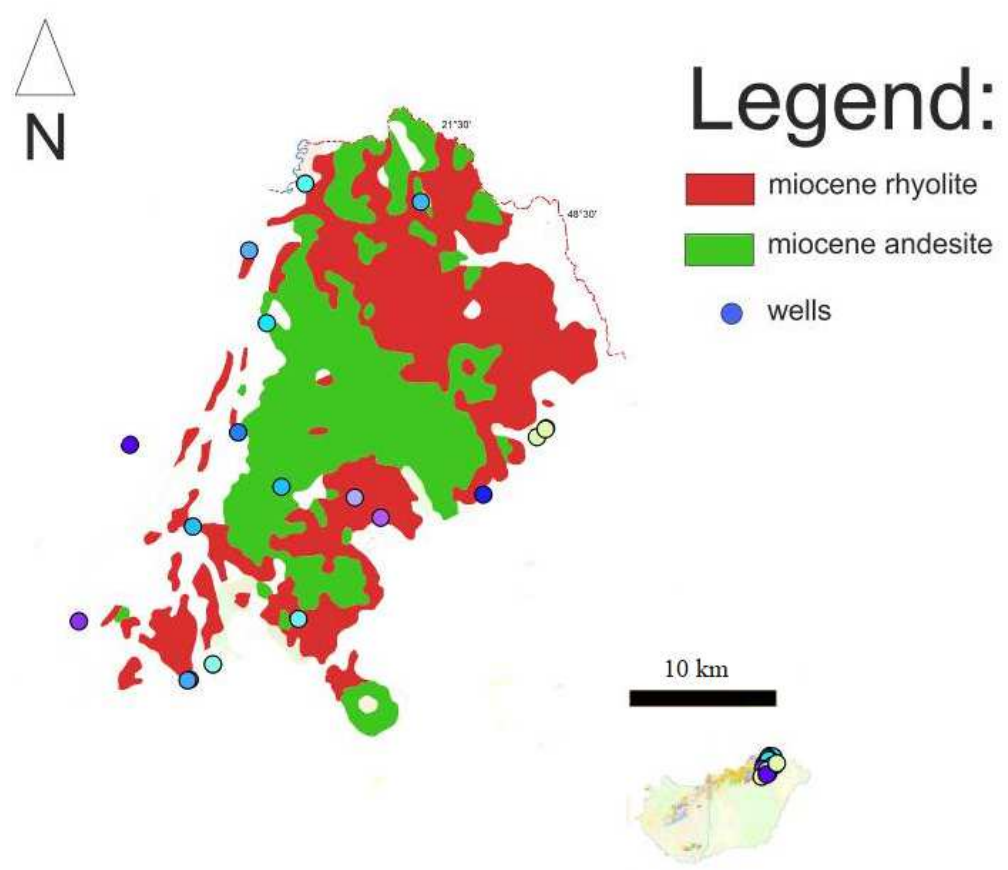

Fig. 9. Wells in the Tokaj Mountains presented on a geological map.

The groundwater flow systems of the volcanic areas can be connected to the local tectonics. The main structural lines of the mountains and the wells are presented in Fig. 10. 


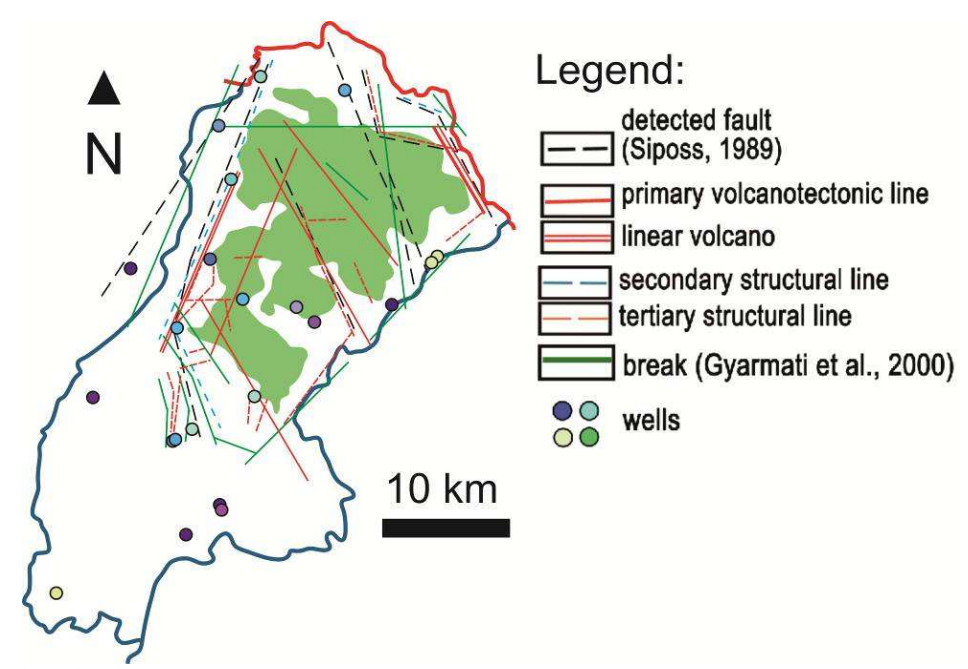

Fig. 10. The location of the main structural lines and the wells of the investigated areas.

The different locations of the known springs and wells were presented on the geological maps. The main reasons for the differences are the tectonics in the mountain and the types of lava rock (andesite, rhyolite). There are much more springs in the northern and eastern part of the mountains than in the other parts. Hence, the distribution of the water samples is not homogeneous (see Fig. 10). A lot of wells in the mountains do not have complete water chemical analyses results. Only 21 wells have the main water chemical parameters for the Piper diagram description. These wells were placed on the tectonical map, and the main tectonical and structural lines were also marked (Fekete et al., 2014).

\section{Description of flow lines using isotope water age information}

Environmental isotopes were measured in some wells and springs to determine the groundwater age, which can give very useful information about the groundwater flow systems. Gönc is one of the most appropriate test areas to prove the conceptual flow model of the mountains. There are many wells with different screen depths in the close neighbourhood of Gönc. The measurement of different environmental isotopes can help the interpretation of groundwater flow systems. The tritium, $\mathrm{O}^{18}$, and $\mathrm{C}^{14}$ isotopes measurements (Szücs et al., 2015:2) of the water samples from those wells and the groundwater age estimates also confirm the validity of the suggested conceptual flow model (Fig. 11).

It can be seen that the groundwater age is increasing with depth, as the length of the flow path is getting longer. For example, the water age is 600-year-old in the 50 meter-deep well. On the other hand, we measured 24000 -year-old groundwater age in a 900 meter-deep well.

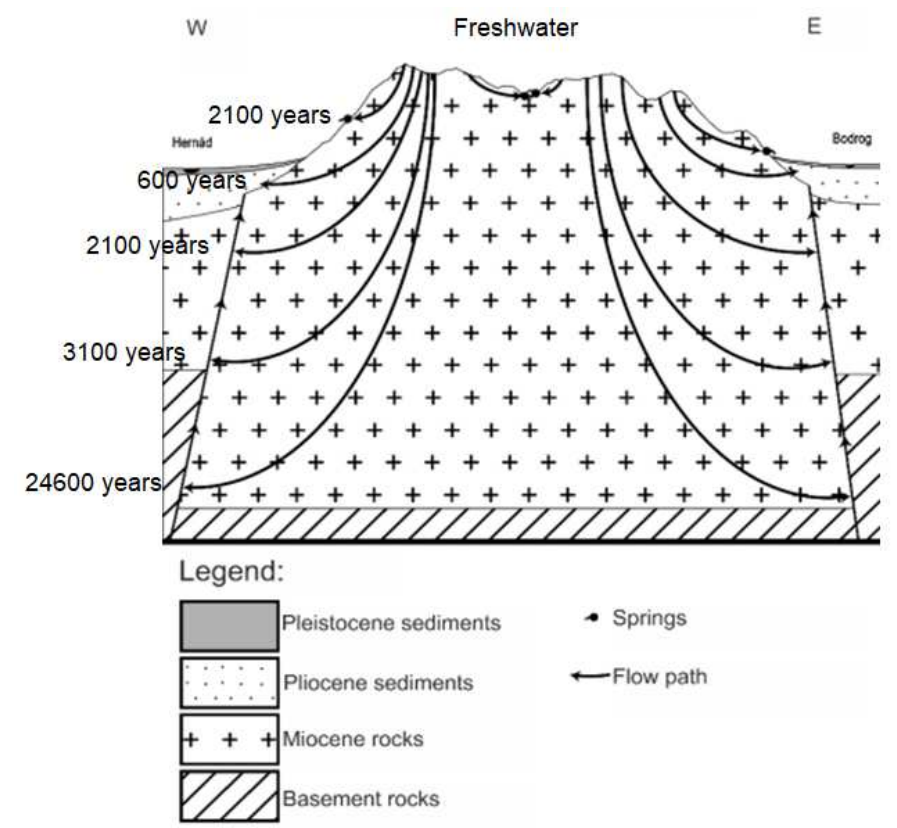

Fig. 11. The apparent water ages in the wells and springs of the Gönc area with the conceptual flow model. 


\section{Local field campaigns to reveal thermal water resources}

Many lukewarm springs were investigated along the main tectonic lines on the discharge areas in order to obtain a more precious picture of the groundwater flow systems. Figure 12 indicates the Hernád tectonic line (red dashed line) with the detected lukewarm springs. Along this path, a set of ground geophysical measurements were carried out to acquire more information about the subsurface geology and the tectonic features.

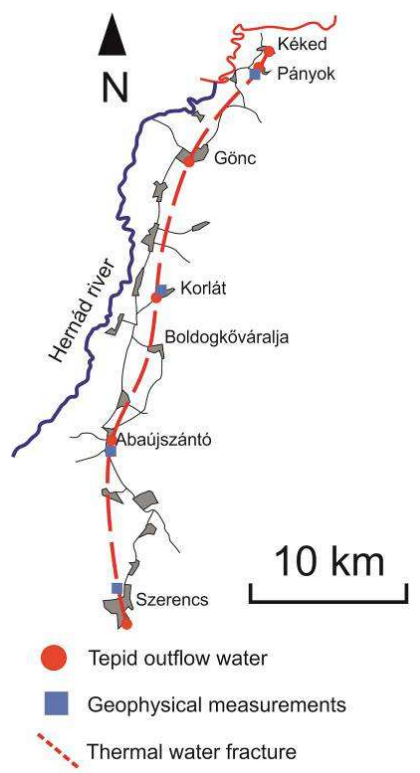

\section{Geophysical surveys in Pányok}

Fig. 12. The location of the Hernád tectonic line.

Pányok is located on the North slopes of the Tokaj Mountains, close to the Hungarian-Slovakian border. The Hasdát creek is flowing through Pányok, and the village is bordered by the Nagy Hill from the South direction, and the Tilalmas and Sátor Hills from the East (Fig. 13). The topography of Pányok changes between 125 and 540 m above sea level (Pinczés, 1998).

The region is built up mostly of volcanic rocks. The oldest formation is made up of effusive andesite, which is stated as the bedrock here. It is followed by weathered, clayey tuffs with around $23-45 \mathrm{~m}$ thickness. The uppermost unit is a thin layer of recent Holocene sediments. The geologic description is given by Szófogadó (1961). The fault lines have North-South directions here, and they have significant effects on the groundwater flow systems. The Hesdát creek follows more or less the fault lines, together with the adjacent Lapis and Csenkő creeks. The lukewarm springs of Kéked can also be found along the Lápis creek.

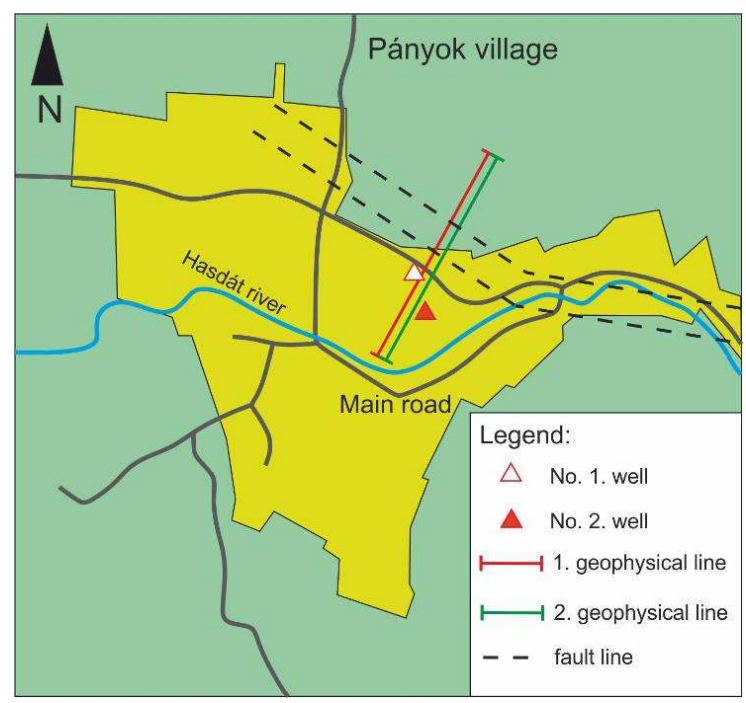

Fig. 13. The location of the wells and geophysical profiles in Pányok. 
The surface geology of the studied area has a significant influence on the groundwater flow. Besides the primary porosity of rocks, depending on petrographic factors, the hydraulic conductivity and storage are affected by the presence of secondary porosity and quality of the fractured zones. Natural replenishment from precipitation can occur mostly through the rhyolitic tuffs and the andesite with low hydraulic conductivities. This means that the recharge value is relatively small.

Most of the wells found in the zone are shallow (below $20 \mathrm{~m})$, providing cold water $\left(10-12^{\circ} \mathrm{C}\right)$. The chemical composition reflects the geologic settings, i.e. low dissolved solid content and relatively high sulfate concentration. Two of the investigated wells in the village demonstrate a high apparent geothermal gradient $\left(240{ }^{\circ} \mathrm{C} / 100 \mathrm{~m}\right)$, with almost the highest groundwater temperatures in the whole mountains. Well No. 1 is located in the North-East part of Pányok. The screen depth of the well is between 26 and $28 \mathrm{~m}$, where the groundwater temperature is $33^{\circ} \mathrm{C}$ and the outflow temperature of $31^{\circ} \mathrm{C}$. Well No. 2 can be found at a $100 \mathrm{~m}$ distance from well No 1 . It is screened deeper at a depth of about $42 \mathrm{~m}$ with an outflow temperature of $28{ }^{\circ} \mathrm{C}$. Based on the field observation, it can be concluded that the NW - SE trending faults have significant effects on the detected upward goundwater flow (Fig. 13). The water chemistry of the two wells suggests a deep flow path and a water age of about several thousand years. The shallow and deep waters show a difference in cationic compounds. The laboratory measurements are indicating that the shallow waters are of calcium type, while the deeper waters are of $\mathrm{Na}$ and $\mathrm{K}$ type. The anionic compositions are similar (bicarbonate and sulfate) for the sampled groundwaters (Fig. 14).

As it was mentioned, the fracture line plays a significant role in the groundwater flow systems. In order to detect the exact positions of these fracture lines, multielectrode DC resistivity measurements had been carried out in Pányok. This method is more efficient than vertical electrical sounding because by moving both the power and potential electrodes along with the surveying profile, not only the vertical but the lateral variation of resistivity of subsurface structures can be imaged. The geophysical measurements had been carried out through two parallel sections, perpendicular to the position of the supposed faults (Fig. 15).

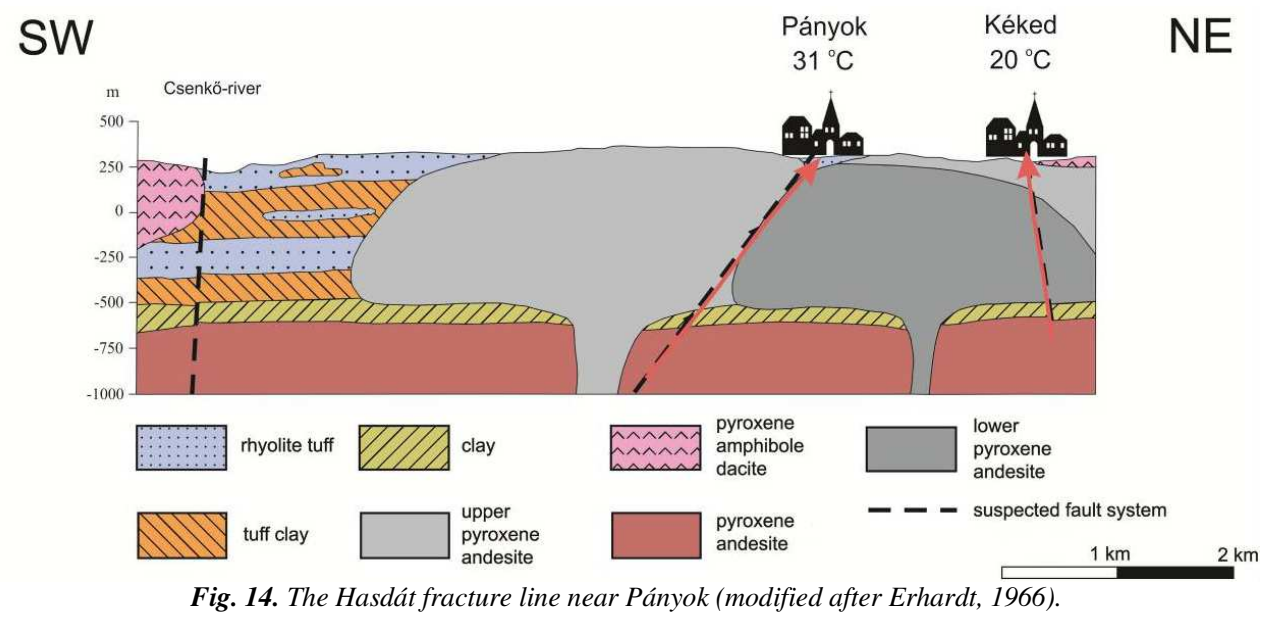

Based on the obtained real resistivity profile (Fig. 15) and the preliminary geological interpretation, a conceptual groundwater flow model had been created (Fig. 16). Based on the water temperatures and the geothermal gradient of the investigated area, the vertical extension of the flow path is assumed about $400 \mathrm{~m}$ deep. The determined age of the collected groundwater samples is around 15,000 years. As it was mentioned earlier, the recharge area is located in the inner and high parts of the Tokaj Mountains. Water moves through fractures and is forced upward near the borders of the mountain through the faults revealed by geoelectric surveying.

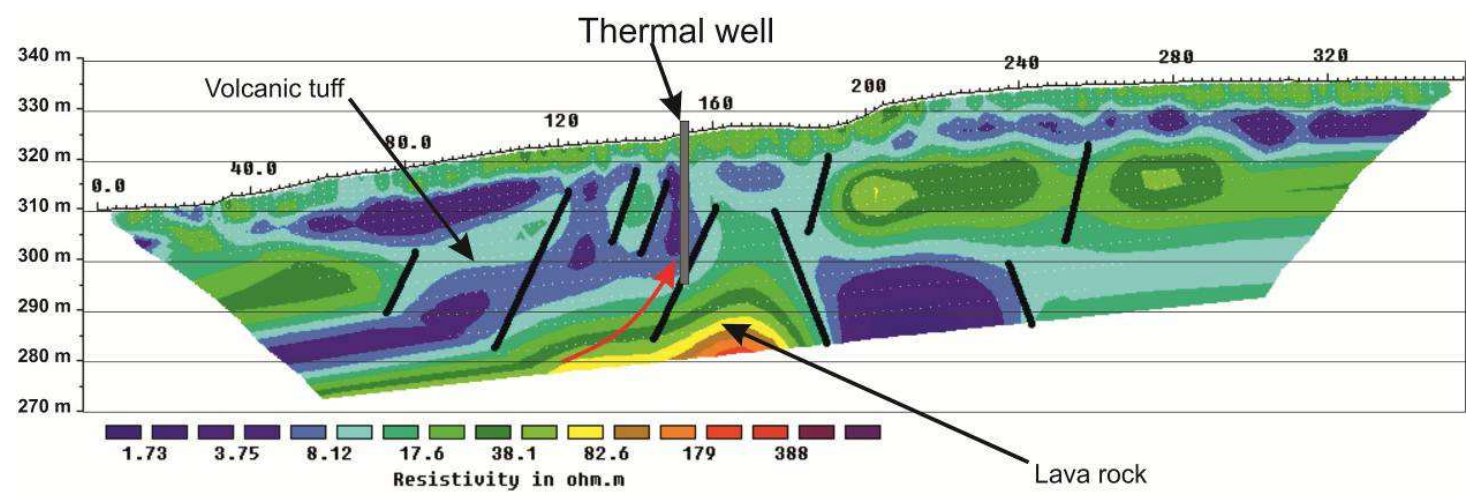

Fig. 15. The NE-SW multielectrode resistivity profile in Pányok. 


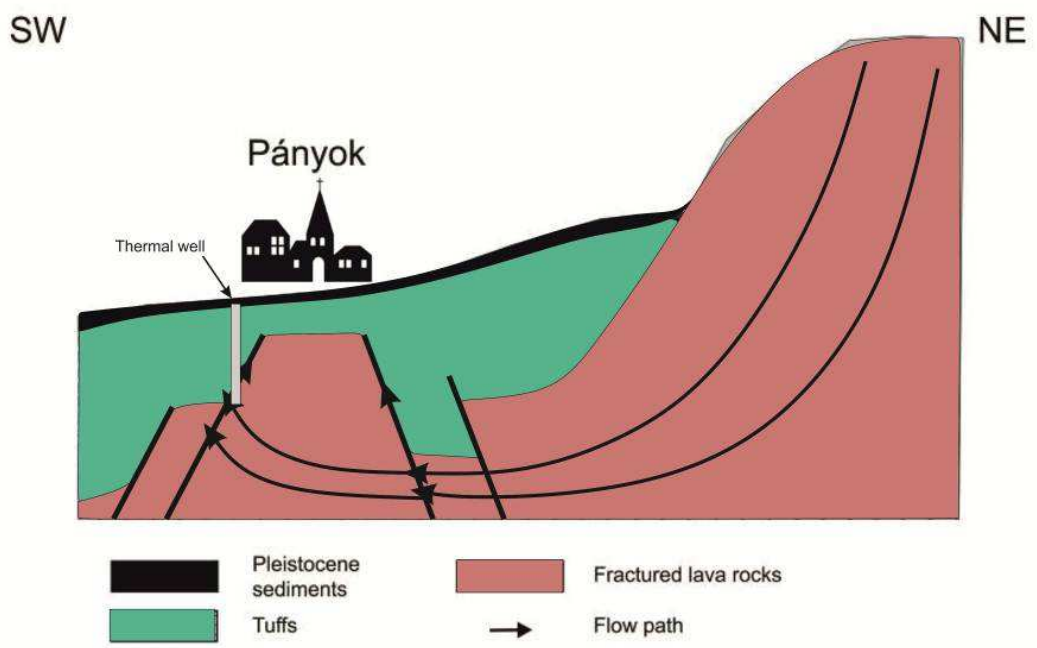

\section{Geophysical surveys in Vizsoly and Korlát}

Fig. 16. Conceptual flow model of the Tokaj Mountains around Pányok.

Vizsoly and Korlát are located at the western border of the Tokaj Mountains. Both settlements have a well providing lukewarm groundwater. The water temperatures of the investigated wells indicate that upcoming groundwater along the fractures reaches the screens of the wells. Based on the measured water temperatures, we are able to estimate the original depth of the produced groundwater. Based on the available information, we supposed a $5^{\circ} \mathrm{C} / 100 \mathrm{~m}$ geothermal gradient for this area. Based on the measured seismic profiles, it can be concluded that the infiltrated water is flowing down to reach the top of the first andesite volcanic formation. Then, the groundwater can continue its way along a fracture line to reach the screen of the well, as the interpreted reflection seismic section shows in Fig. 17.

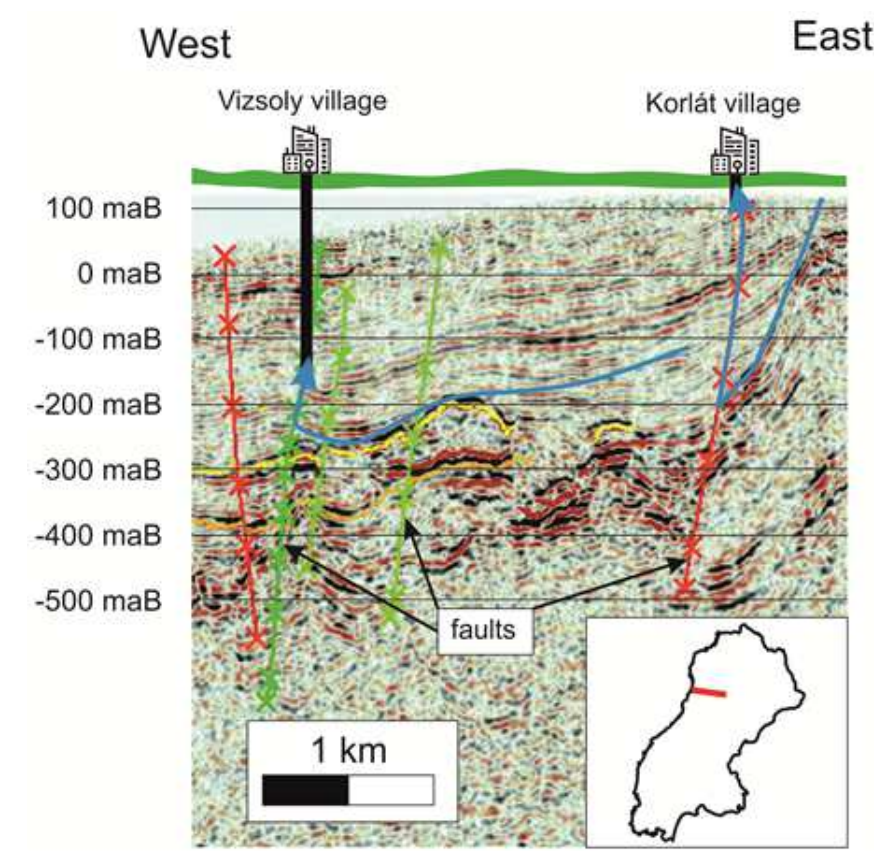

Fig.17. Seismic reconstruction of flowing path system of the investigated wells at Vizsoly and Korlát.

Multielectrode DC resistivity measurements were also carried out to determine the positions of the fracture lines, which can deliver thermal water to the screens of the wells (Szücs et al., 2015:1). The apparent resistivity data were inverted using a 2D block inversion scheme using the RES2DINV method (Geotomo software). The inversion procedure found the optimum after 20 iteration steps. At the end of inverse modelling, the distance between the measured and calculated data is $\mathrm{RMS}=2.4 \%$. The obtained resistivity section of the geophysical interpretation can be seen in Fig. 18. 


\section{East}

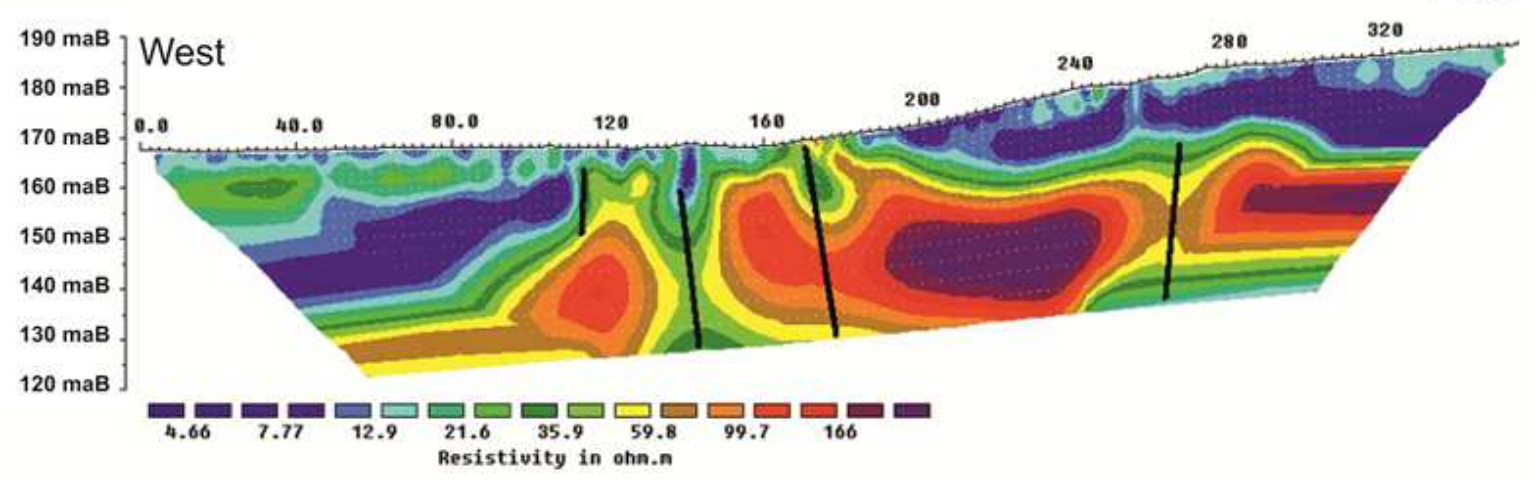

Fig. 18. Results of the inversion of multielectrode DC resistivity data measured at Korlát.

It can be seen on the resistivity tomogram that the fracture lines can nearly reach the surface. On the other hand, some andesite upthrust structures can also be observed. The groundwater can rise from the deep along these fracture lines. The King lake is located in the neighbourhood of the Korlát settlement. There are two springs at the bottom of the lake. Measurement was carried out on 3 September 1953. The production rate was 778 liters/minute, the temperature was $25^{\circ} \mathrm{C}$, and the water had high dissolved iron and sulfur content. The lake cannot be frozen during the wintertime because of the warm water recharge at the bottom.

\section{Geophysical surveys in Szerencs}

The higher levels of the Árpád peak in Szerencs are covered with hydrothermal quartz, while the hollows are covered with lake water quartz (Miklós, 2003). We measured the potential temperature values of the depth from the temperature of effluent water to complement the lack of geothermic data of the given depth. From this information, we defined the geothermal gradient, which is $7.1{ }^{\circ} \mathrm{C} / 100 \mathrm{~m}$, hereinafter we used it as a constant in this area.

In the surroundings of Szerencs, there is a North-Eastern hydrothermal zone (Fig. 19). Further to the south, it tends to the deep and can only be traced in the stratigraphical lines of drills. The filtering of the transverse drills through the hydrothermal quartz is on this layer because of its high permeability. Because hot water flows in the hydrocartzite layer, reference points were designated at the locations where the presence of hydrocartzite was recorded. When further geophysical experiments show the continuation of hydrothermal quartz to the depth (around $360 \mathrm{~m}$ at the periphery border), the base temperature could be about $39^{\circ} \mathrm{C}$. In this case, the temperature of effluent water is around $37^{\circ} \mathrm{C}$. Surface geoelectrical investigations should be carried out in Vince Tanya (a dairy farm) to the south of Szerencs (Szücs et al., 2012). Resistivity surveying profiles, including the locations of measuring points, are included in Fig. 20.

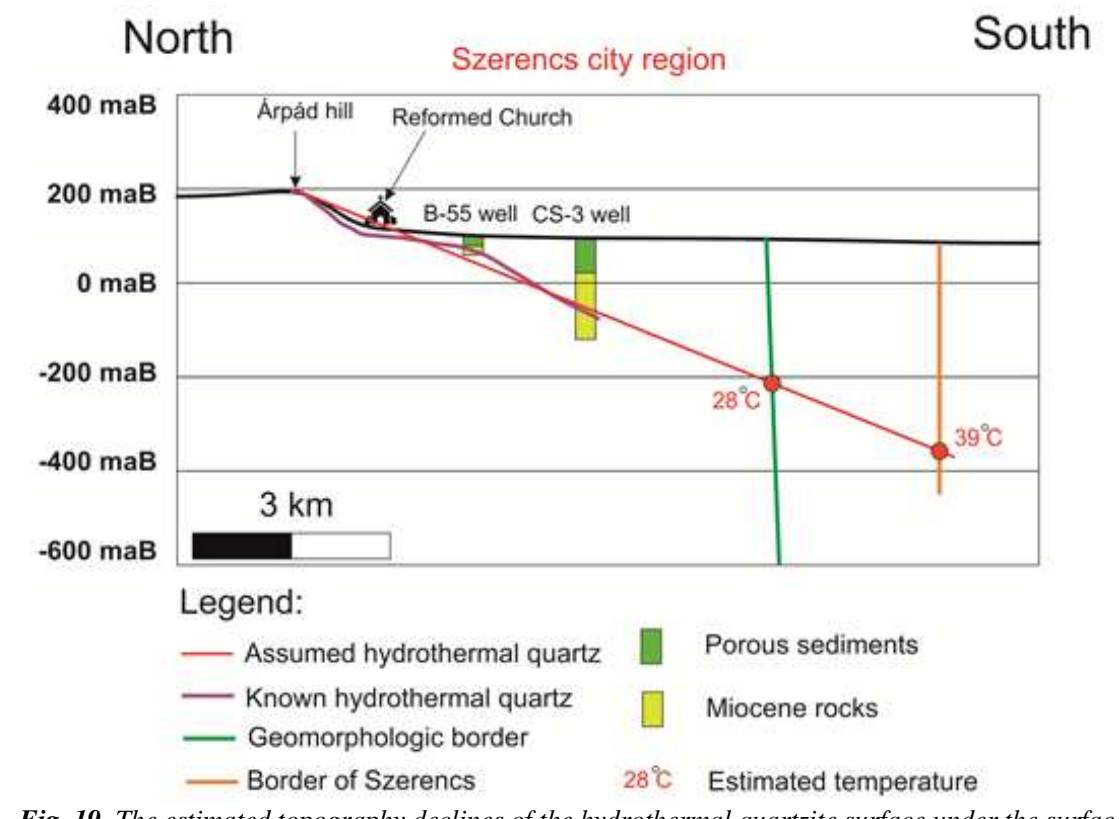


In 2013, surface geophysical measurements were conducted in Szerencs for geothermal exploration. We have combined geoelectric, magnetic and hydrogeological approaches for a comprehensive interpretation of the groundwater structure. The vertical electrical sounding (VES) and the multielectrode DC resistivity measurements are combined and interpreted by a 2.5 D series expansion-based inversion method developed by Gyulai and Tolnai (2012). When estimating the series expansion coefficients belonging to sinusoidal basis functions, the inverse problem is solved at a high overdetermination ratio. The large data-to-unknowns ratio assures highly accurate and reliable inversion results. The result of the inversion process can be seen in Fig. 21.

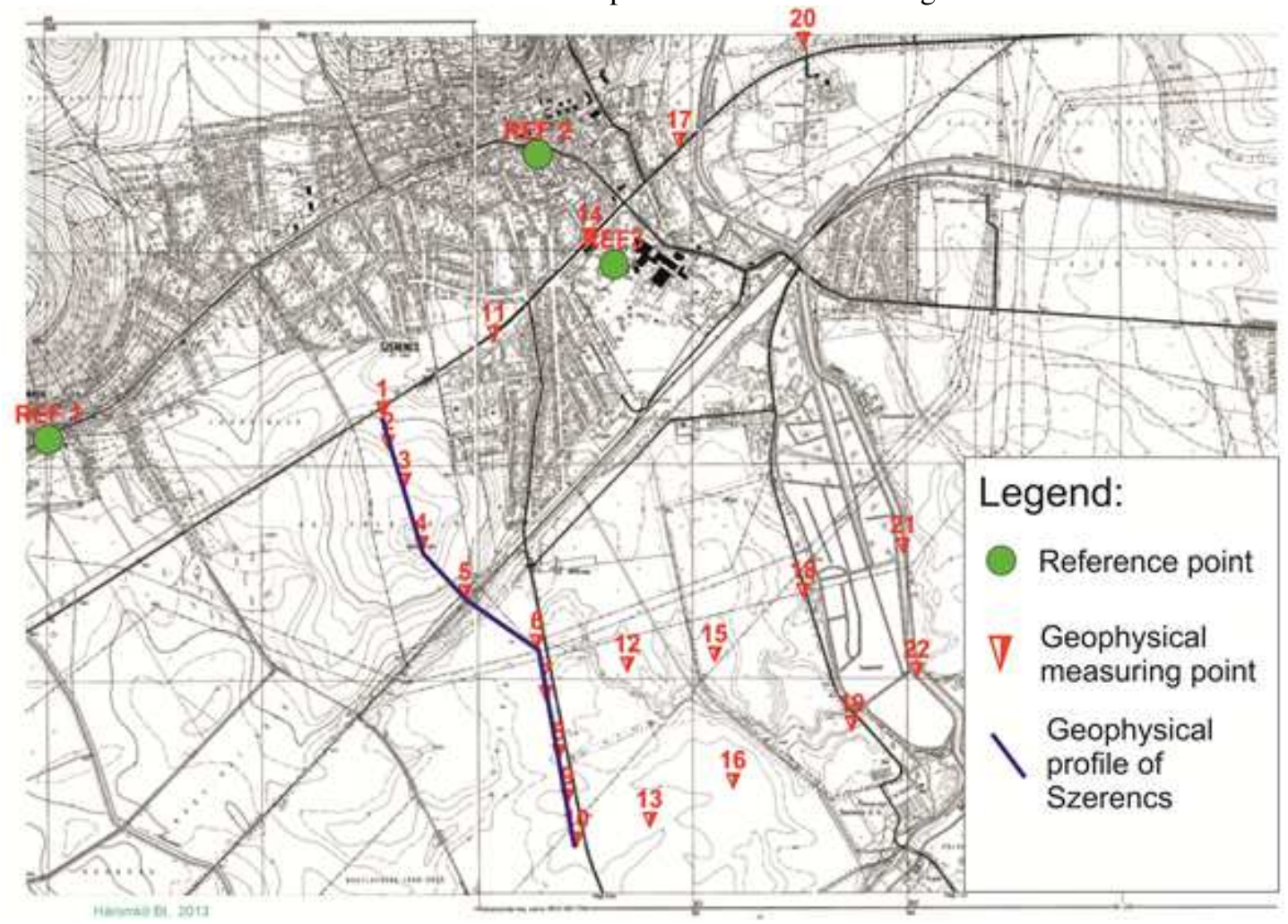

Fig. 20. Surface geoelectrical measuring points located in the vicinity of Szerencs (modified after Gyulai et al. 2017).

The inversion results show a fault system in the deep domains of the research area. The detection of this fracture was the main goal of the research. The perception of its presence can be detected by surface geophysical methods (VES, magnetic methods). The deep warm water flows through the fault system and then flows up to the shallow monitoring wells. In the investigated area, three different layers can be found. The cover is Pannonian sediment (green), the middle layer is weathered volcanic tuff (blue), and the bottom is the Miocene lava rocks, like andesite or rhyolite (Fig. 21). The sudden position change of the lava rock marks the fault in the depth (Fig. 22).

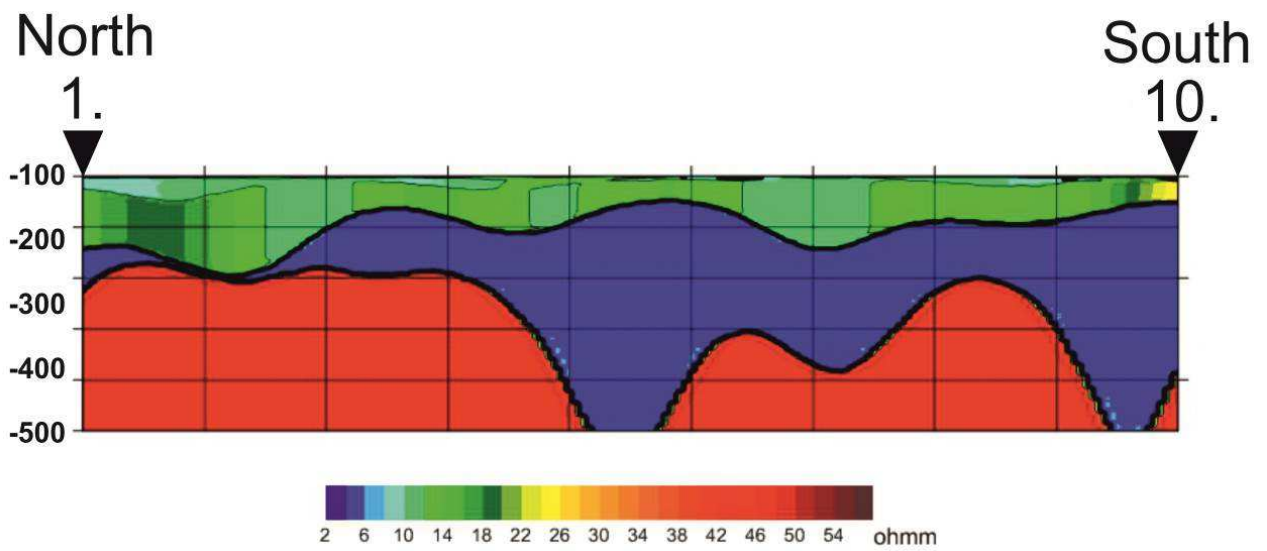

Fig. 21. 2.5 D inversion of VES measurements measured along the Szerencs I. profile (N-S) (modified after Gyulai et al. 2017). 


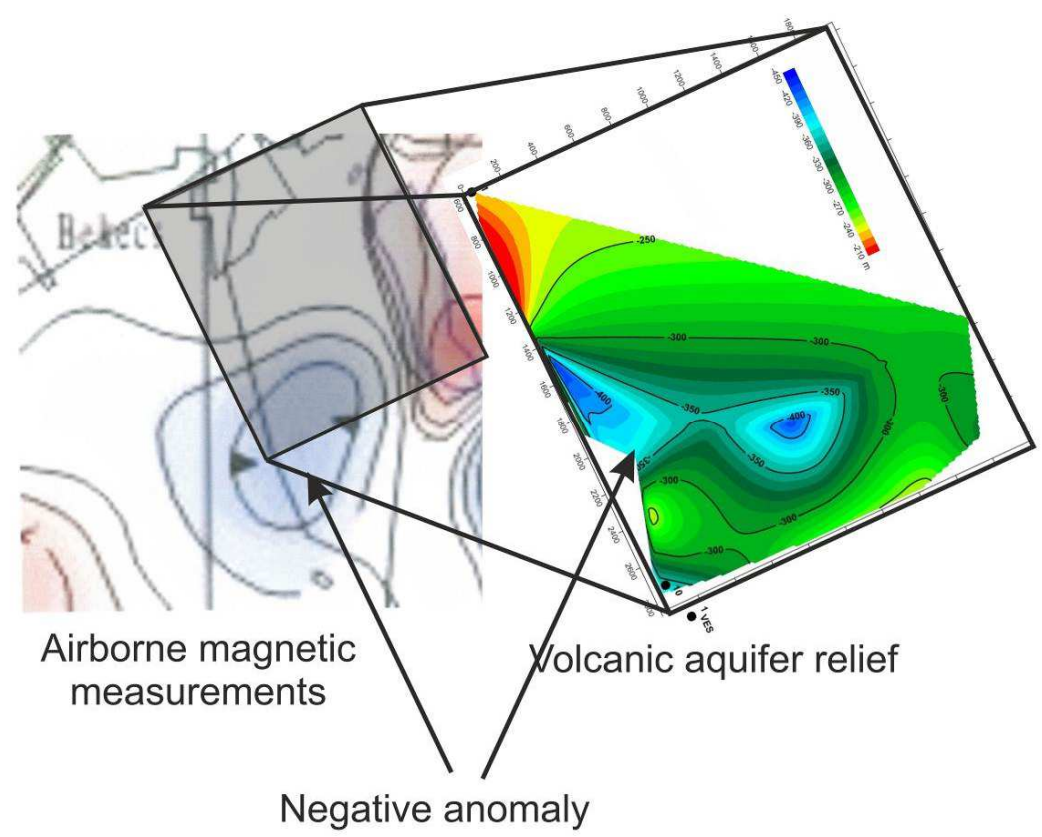

Fig. 22. Comparing airborne magnetic map with the result of geoelectric interpretation (modified after Gyulai et al. 2017).

\section{Regional hydrodynamic flow model of the Tokaj Mountains}

By analyzing the data of all wells and springs in the area and using the results of the previous research, we created the hydrogeological and water chemistry database of the Tokaj Mountains as it was described earlier. It was also an important goal to create a regional scale groundwater flow model to have a general idea about the water budget and the available groundwater resources, including sustainability aspects. During the modelling, we also used the hydrological logs of the wells, the geophysical results and all the knowledge, which we can obtain from field measurements. The main objective of the modelling phase was to determine how much shallow groundwater and thermal water can be produced in a sustainable way on a regional scale. During the modelling, the USGS MODFLOW program (Langevin et al., 2017) package was used- part of the GMS program (Aquaveo, 2019) - to simulate the flow conditions in the Tokaj Mountains.

The surface elevation data of the modelled area were taken from an SRTM satellite digital image, which is also the top layer of the flow model. The bottom layer of the model- the bedrock - was based on geophysical measurements, which were introduced into the GMS program after digitization. 172 drilling data were used for the further spatial geology, and then we simplified the geological structure and distinguished 4 layers (Pleistocene, Pannonian, Miocene and the bedrock). For the model calculations, the bedrock was assumed to be impermeable. The modelled area is an irregular polygon ( $48 \times 77 \mathrm{~km}$ site length). The border of the model is lined by the Great Milic on the north side, while in the other directions, the boundaries are drawn on terrain units. The model net was evenly divided into 200 x 200 m cells to obtain a model net of 372 lines and 290 columns. The model was divided vertically into 4 main structures and a total of 7 model layers to simulate flow paths (Fig. 2). The surface of each model layer was considered spatially variable by interpolating the layer thicknesses obtained from the drilling rows and the hydrogeological logs of the wells to the modelled area and forming the surface of the layers (Zákányi et al., 2015).

The vertical leakage factors were determined based on the hydrogeological nature. When preparing the piezometric levels of the layers, we took into account the water levels of the wells and the locations of the springs. Of course, the water levels were corrected to the surface. In the northern part of the model, we set "no flow", while in the other parts, we set specific boundary conditions on the edges (Fig. 23). Infiltration was given to the model area by zoning. The production wells were also put into the steady-stare flow model with their average production rates. The groundwater level measurements were available for the model calibration. The simulated groundwater levels of the calibrated flow model can be seen in Fig. 24. The RMSE (root mean square error) value of the model calibration is less than 0.9 meter, which is a relatively good value in the case of a regional scale flow model.

It is important to determine that how much groundwater can be produced in a sustainable way on the regional scale. Different drawdown simulations were carried out to determine how much cold and thermal water can be produced from the model area. It can be concluded that $15000 \mathrm{~m}^{3} /$ day groundwater can be produced in a sustainable way to provide drinking and industrial water supply. Additionally, along the detected fracture lines, $3000 \mathrm{~m}^{3} / \mathrm{day}$ thermal water with a temperature range of $30-45^{\circ} \mathrm{C}$ can be produced, which is a very important new result. It gives the opportunity for tourism, hotel, wellness or spa developments in this interesting touristic region. 


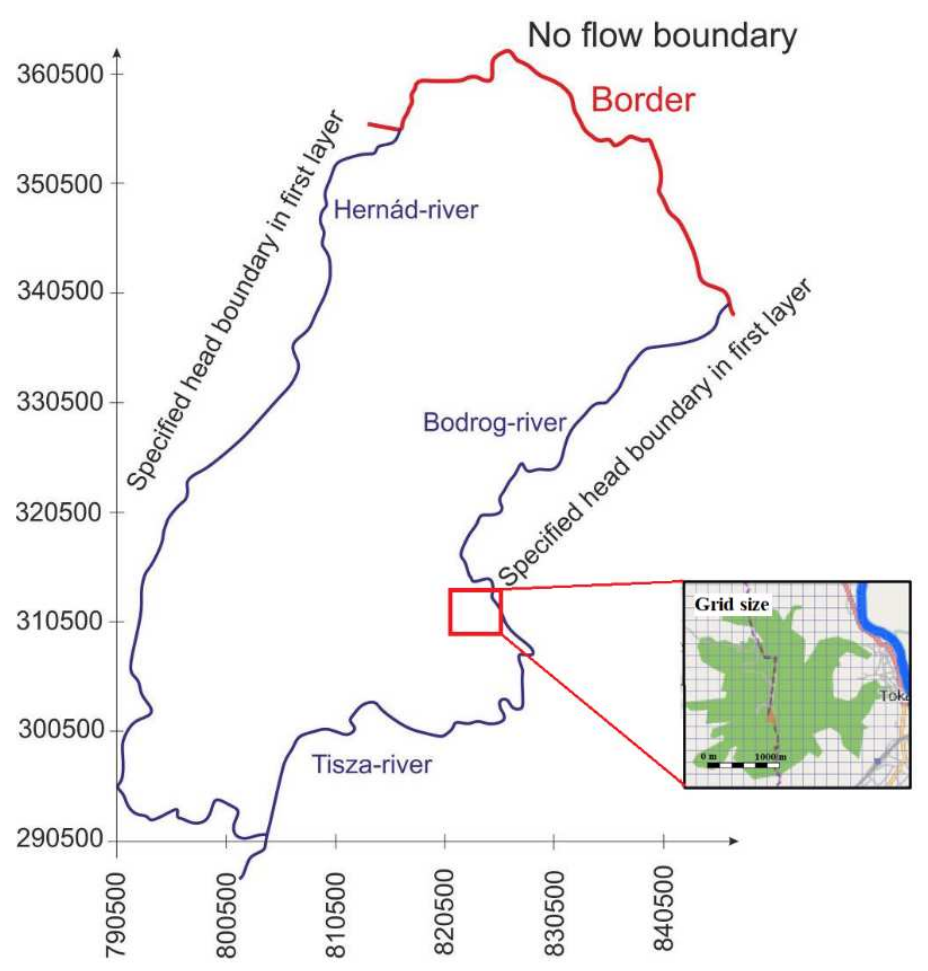

Fig. 23. The boundary conditions of the regional flow model.

\section{Calculated water level ( $\mathrm{mBf}$ )}

500.00

455.00

410.00

365.00

320.00

275.00

230.00

185.00
140.00

95.00

50.00

- Observation well
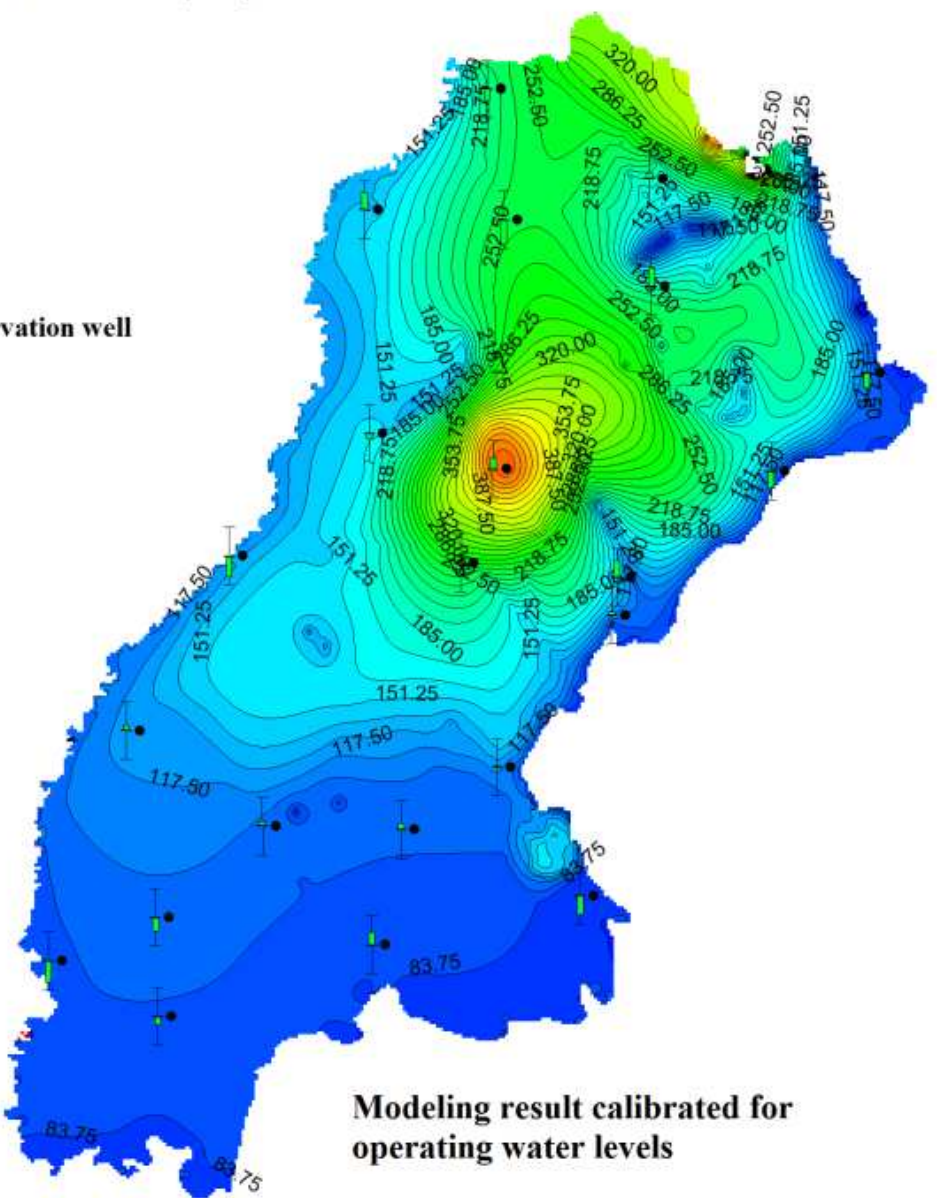

L.

Fig. 24. The calibrated regional-scale groundwater flow model. 


\section{Discussion}

The paper is the first one to describe the regional scale hydrogeological conditions of the Tokaj Mountains in Hungary. All the maps visualized in this pioneering work are original and the common work of the authors. The realized new field measurements and the outlined hydrogeological interpretation provide valuable information to manage groundwater resources in a sustainable way in this region in the future. The whole work was supported by a regional scale MODFLOW groundwater model to describe the water budget of the investigated aquifer systems accurately. The environmental isotope investigations proved the importance of the fracture and faults zones at the test area to utilize the limited thermal water resources. The natural groundwater recharge is also limited as the whole area is a volcanic region. It will be important to investigate in the near future how extreme weather conditions can affect the identified groundwater flow systems at the Tokaj Mountains.

The hydrogeological results are effectively supported by field geophysical measurements. The study shows a successful application of the $2.5 \mathrm{D}$ series expansion based inversion methodology applied to a combined geoelectric dataset, including several VES stations and multielectrode profiles. The joint inversion of geoelectric data improves the accuracy and reliability of inversion results compared to traditional inversion approaches (for example, 1D VES inversion). Focusing on the aquifer zones, the lateral variation of rock interfaces and resistivity distributions can be further refined by using appropriate basis functions in series expansion giving new perspectives for locating the fracture zones. To achieve better spatial resolution, additional - even unconventional - geoelectric arrays are planned to be used. The selection of a proper array can be established on parameter sensitivity studies. For instance, pilot surveys are recommended to be made using quasi-null arrays, which showed previously innovative solutions in hydrogeologic applications to other Hungarian groundwater bodies (Szücs et al., 2021). The series expansion based inversion methodology shown in the paper applies an automated weighting process giving a robust solution to the inversion of different datasets, which seems to be fruitful to be combined with different measurement methodologies. To make the estimation process more independent from the initial geoelectric model - which is based on rather poor information in the given area - we suggest the use of a genetic algorithm tool in combination with the applied inversion methodology (Szabó, 2018). In further studies, more types of suitable hydrogeophysical methods will be involved for more detailed investigations in the scrutinized area. In the identification of porous formations with good storage capacity, multivariate statistical interpretation of wireline logs using cluster analysis allows reliable separation of potential aquifers. Their basic petrophysical (porosity, shale content etc.) and hydraulic properties (hydraulic conductivity and transmissivity) can be extracted by machine learning-based factor analysis of well logs (Szabó, 2015; Szabó and Dobróka, 2018) or by using sitespecific information directly derived from well logging parameters (Szabó et al., 2015; Szücs et al., 2021). For a more reliable characterization of groundwater formations, a comprehensive interpretation of surface and borehole geophysical methods - including new measurement methodologies and advanced inversion techniques - and hydrogeology tests can be recommended for meeting challenges in local hydrogeology.

\section{Conclusions}

The Tokaj Mountains are one of the most well-known volcanic mountain regions in Hungary. The geology and the mineralogy of the area have been studied thoroughly; however, we have relatively little knowledge about the hydrogeological features. Limited research on the hydraulics of groundwater and water-rock interactions had been performed earlier at local sites, but a detailed understanding of the flow system was also lacking. We improved significantly the description of regional hydrogeology of the investigated area using the available data and new multidisciplinary field measurements made by us. The prepared conceptual flow model highlighted the importance of the tectonic and fracture lines concerning the groundwater flow systems. It is also important to mention that the regional flow model was also prepared to serve groundwater management purposes. The regional model was first calibrated to the static water level and then taking into account the dynamic water levels of the wells was carried out model runs. In a refined flow model, we are able to estimate the flowing direction and the volume of the drinking water, mineral and medicinal water and thermal water. Based on water chemistry, water temperature and water measurements, the model was refined, and the fracture system was cleared on its western side. The Hernád line has been able to detect this hot water fracture system on several locations using hydrogeophysical tests.

\section{References}

Aquaveo LLC. (2019): Groundwater modeling system GMS 10.4 software.

Bobok, E., Tóth, A. N., Szücs, P., Fejes, Z. (2014): Methodology for Determining Geothermal Potential; PROCEEDINGS, Thirty-Ninth Workshop on Geothermal Reservoir Engineering Stanford University, Stanford, California, February 24-26 
Erhardt, Gy. (1966): Geological map of the Tokaj Mountains. Series 25000. Map of Tornyosnémeti.

Fejes, Z., Szücs, P. (2013): Potential Tepid and Hot Water Resources in the Tokaj Mountains; Geosciences and engineering, Publication of the University of Miskolc, (3.) pp. 101-109.

Fekete, Zs., Fejes, Z., Szücs, P., Gonda, N. (2014): Hydrochemical characterization of the Tokaj Mountains; Xth International Scientific Conference on Mineral Waters of the Carpathian Basin. pp. 53-62.

Gyalog, L. (2005): Covered geological map of Hungary 1: 100000, Budapest

Gyulai, Á., Tolnai É. (2012): 2.5D geoelectric inversion method using series expansion; ACTA GEODAETICA ET GEOPHYSICA HUNGARICA 47:(2) pp. 210-222.

Gyulai, Á., Szücs, P., Turai, E., Baracza, M. K., Fejes, Z. (2017): Geoelectric Characterization of Thermal Water Aquifers Using 2.5D Inversion of VES Measurements. SURVEYS IN GEOPHYSICS 38:(2) pp. 503-526.

Kiss, G. (2007): The name of the mountain, boundaries and landscapes; The Zemplén Nature Protected Area, Eger, Bükki publisher

Langevin, C. D., Hughes, J. D., Banta, E. R., Niswonger, R. G., Panday, S., and Provost, A. M. (2017): Documentation for the MODFLOW 6 Groundwater Flow Model. Techniques and Methods 6-A55. U.S. Geological Survey, Reston, Virginia pp. 1-197. https://doi.org/10.3133/tm6A55.

Madarász, T., Szücs, P., Kovács, B., Lénárt, L., Fejes, Z., Kolencsik-Tóth, A., Székely, I., Kompár, L., Gombkötő, I. (2015): Recent trends and activities in hydrogeologic research at the University of Miskolc, Hungary; Central European Geology, Vol. 58/1-2, pp. 171-185. DOI: 10.1556/24.58.2015.1-2.11

Miklós, G. (2003): Warm water supply possibilities in Szerencs region; Geokomplex Kft, Miskolc (2003)

Molnár, F., Nagymarosy, A., Jelen, S., Baco, P.: Minerals and wines: Tokaj Mts., Hungary and Slanské vrchy Mts., Slovakia; ACTA MINERALOGICA-PETROGRAPHICA, FIELD GUIDE SERIES, VOL. 15, pp. 140. (2010)

Peeters, L. (2013): A Background Color Scheme for Piper Plots to Spatially Visualize Hydrochemical Patterns; Groundwater, Volume 52, Issue 1, pp. 1-6. DOI: 10.1111/gwat.12118

Pinczés, Z. (1998): Large geomorphological forms of the Tokaj Mountains; Geographical Notice (3), pp. $379-393$. (1998)

Székely, F., Szücs, P., Zákányi, B., Cserny, T., Fejes, Z. (2015): Comparative analysis of pumping tests conducted in layered rhyolitic volcanic formations; Journal of Hydrology, ELSEVIER 520, pp. 180-185. http://dx.doi.org/10.1016/j.jhydrol.2014.11.038

Szófogadó, P. (1961): The hydrogeological significance of the Göncz-fortune fracture, with special regard to the water supply of the Abaújszántó beach; Hidrogeológiai közlöny, 41 (2), pp. 145-148.

Szabó, N.P. (2015) Hydraulic conductivity explored by factor analysis of borehole geophysical data. HYDROGEOLOGY JOURNAL 23, 869-882.

Szabó, N.P., Kormos, K. \& Dobróka, M. (2015) Evaluation of hydraulic conductivity in shallow groundwater formations: a comparative study of the Csókás' and Kozeny-Carman model. ACTA GEODAETICA ET GEOPHYSICA 50, 461-477.

Szabó, N.P. (2018) A genetic meta-algorithm-assisted inversion approach: hydrogeological study for the determination of volumetric rock properties and matrix and fluid parameters in unsaturated formations. HYDROGEOLOGY JOURNAL 26, 1935-1946.

Szabó, N.P., Dobróka, M. (2018) Exploratory Factor Analysis of Wireline Logs Using a Float-Encoded Genetic Algorithm. MATHEMATICAL GEOSCIENCES 50, 317-335.

Szücs, P., Fejes, Z., Kompár, L. (2012): Thermal water research in Szerencs region for the purpose of geothermal energy; MicroCAD: XXVI. International Scientific Conference, pp. 201-206.

Szűcs, P., Fejes, Z., Zákányi, B., Fekete, Zs., Szárnya, G., Hartai, É., Turai, E. Gyulai, Á., Szabó, P. N., Cserny, T. (2014): General Characterization of Mineral and Thermal Water Resources in the Tokaj Mountains; Geosciences and Engineering: A Publication of the University of Miskolc 3:(5) pp. 77-82.

Szűcs, P., Fejes, Z., Zákányi, B., Székely, F., Turai, E. Gyulai, Á., Szabó, P. N., Baracza, K. (2015:1): The Improvement of the Regional Flow Model of the Tokaj Mountains with the Help of Geophysical Inversion Methods; Geosciences and engineering, Publication of the University of Miskolc, (4:6) pp. 116-124.

Szücs, P., Kompár, L., Palcsu, L., Deák, J. (2015:2): Estimation of groundwater replenishment change at a Hungarian recharge area; CARPATHIAN JOURNAL OF EARTH AND ENVIRONMENTAL SCIENCES (10:4) pp. 227-246.

Szücs, P.; Szabó, N.P.; Zubair, M.; Szalai, S. (2021) Innovative Hydrogeophysical Approaches as Aids to Assess Hungarian Groundwater Bodies. APPLIED SCIENCES, 11, 2099.

Zákányi, B., Fejes, Z., Szűcs, P., Székely, F. (2015): WATER MANAGEMENT FOR REGIONAL MODEL OF THE TOKAJ MOUNTAIN REFINEMENT AND CALIBRATION; Müszaki Tudomány az Észak-kelet Magyarországi Régióban, pp. 592-597. 